GA-A16154

This book was prepored as an account of work spcnsored by an agency of the Un ted States Government Netther the United States Government nor dily agency thereof nor any of their employees makes any wamplereness or or tholed or assumes any legal liability or responsib lity for the accurad reoresents that its use would not nfrnge or wardy owned tights Peference herens to dsclosed or

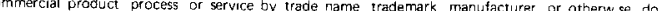

\title{
FISSION PRODUCT BEHAVIOR IN \\ THE PEACH BOTTOM AND FORT ST. VRAIN HTGRS
}

\author{
by \\ D. L. HANSON, N. L. BALDWIN, and D. E. STRONG
}

This is a preprint of a paper to be presented at the IAEA Specialists' Meeting on Coolant Chemistry, Plateout, and Decontamination, December 2-4, 1980, Jïlich, Federal Republic of Germany, and to be published in the Proceedings.

\author{
Work supported by \\ U.S. Department of Energy \\ Contract DE-ATO3-76ET35300
}

GENERAL ATOMIC PROJECT 6400

NOVEMBER 1980

\section{GENERAL ATOMIC COMPANY}




\section{DISCLAIMER}

This report was prepared as an account of work sponsored by an agency of the United States Government. Neither the United States Government nor any agency Thereof, nor any of their employees, makes any warranty, express or implied, or assumes any legal liability or responsibility for the accuracy, completeness, or usefulness of any information, apparatus, product, or process disclosed, or represents that its use would not infringe privately owned rights. Reference herein to any specific commercial product, process, or service by trade name, trademark, manufacturer, or otherwise does not necessarily constitute or imply its endorsement, recommendation, or favoring by the United States Government or any agency thereof. The views and opinions of authors expressed herein do not necessarily state or reflect those of the United States Government or any agency thereof. 


\section{DISCLAIMER}

Portions of this document may be illegible in electronic image products. Images are produced from the best available original document. 
FISSION PRODUCT BEHAVIOR IN THE PEACH BOTTOM

AND FORT ST. VRAIN HTGRS

by

D. L. Hanson, N. L. Baldwin, and D. E. Strong

General Atomic Company

San Diego, California, U.S.A.

\begin{abstract}
Actual operating data from the Peach Bottom (PB) and Fort St. Vrain (FSV) High-Temperature Gas-Cooled Reactors (HTGRs) have been compared with code predictions to assess the validity of the methods used to predict the behavior of fission products in the primary coolant circuit. For both reactors the measured circuit activities were significantly below design values, and the observations generally verify the codes used for large HTGR design.

The PB primary circuit after seven years of operation was exceptionally clean. A fuel element purge system virtually eliminated the release of fission gases into the primary coolant circuit. Extensive examinations at endof-life revealed that only $\mathrm{Cs}$ and trace amounts of $\mathrm{Sr}$ had plated out in the circuit. Their plateout distributions were in excellent agreement with PAD code predictions. Most of the deposited activity was associated with carbonaceous surface films which resulted from occasional small inleakages of lubricating oil.
\end{abstract}

Primary circuit activities in FSV during the first cycle were also very low. Noble gas activity was about $1 \%$ of the design limit; and the circulating lodines were at least one order of magnitude below the limit, although the measurement uncertainties are significant. The plateout per pass of the iodine isotopes increased with decreasing half-life (the value for I-131 is about $1 \%$ per pass) as predicted with the PADLOC code. Gamma scanning of two helium circulators indicated very low plateout activities. Iodine-131 was the principal fission product observed, along with small amounts of Cs-134, $\mathrm{Cs}-137$, and $\mathrm{Ba} / \mathrm{La}-140$.

\title{
1. INTRODUCTION
}

The quantity and distribution of radionuclides in the primary coolant circuit are of fundamental importance to reactor design. They affect, for example, not only shielding requirements and maintenance procedures but safety analyses as we11. In the case of the High Temperature Gas-Cooled Reactor (HTGR), actual operating experience is limited, and the circuit activities must be established largely by theoretical predictions. Typically, 
these predictions are made with complex computer codes which must be verified to establish the adequacy of the design. The most rigorous test of such transport codes is their ability to reproduce actual reactor performance. Therefore, to assess the validity of the design methods used at General Atomic (GA), actual operating data from the Peach Bottom (PB) and Fort St. Vrain (FSV) HTGRs have been compared with code predictions. For both reactors the measured circuit activity levels were significantly below the design limits, and the observations generally verify the codes used for large HTGR design.

Before the results are presented, the design methods used at GA to predict primary circuit activities will be briefly reviewed.

\section{FISSION PRODUCT DESIGN METHODS}

Prediction of primary circuit activities is a two-step process. First, the release rates of fission products from the reactor core must be calculated, and then their distribution in the primary circuit must be determined. Given the charter of this conference, the latter will be emphasized here. The distribution of condensible nuclides between the coolant and the surfaces of the primary circuit and the distribution of deposited, or "plated out," activity must both be considered.

At GA, plateout calculations are made with the PADLOC code (Ref. 1) or with its predecessor, the PAD code (Ref. 2). While the physical models are analogous, PADLOC is more flexible and orders of magnitude more efficient than PAD. Both codes are transient, one-dimensional mass transfer codes. Numerical solutions are obtained for the coupled, nonlinear differential equations describing the conservation of mass between the coolant and the surface with a convective boundary condition. The coolant and surface concentrations are coupled by an equilibrium adsorption process which can be described by either linear or nonlinear sorption isotherms. A simplified set of equations is given below.

Coolant Mass Balance

$$
\begin{aligned}
\partial \mathrm{C} / \partial \mathrm{t}+ & \mathrm{V} \partial \mathrm{C} / \partial \mathrm{X}=\mathrm{B}-\begin{array}{c}
\lambda \mathrm{C} \\
\text { Convection }
\end{array}-\mathrm{kP} / \mathrm{A}\left(\mathrm{C}-\mathrm{C}_{\mathrm{S}}\right) \\
\text { Source } & \begin{array}{r}
\text { Decay } \\
\text { Mass Transfer }
\end{array} \\
\text { where } \mathrm{C} & =\text { coolant concentration, } \mu \mathrm{g} / \mathrm{cm}^{3}, \\
\mathrm{t} & =\text { time, sec, } \\
\mathrm{X} & =\text { distance, } \\
\mathrm{B} & =\text { coolant source rate, } \mu \mathrm{m} / \mathrm{cm}^{3}-\mathrm{sec}, \\
\lambda & =\text { decay constant, } \mathrm{sec}^{-1}, \\
\mathrm{k} & =\text { mass transfer coefficient, cm/sec, } \\
\mathrm{C}_{\mathrm{S}} & =\text { coolant concentraton in the boundary layer, } \mu \mathrm{g} / \mathrm{cm}^{3}, \\
\mathrm{P} & =\text { wetted perimeter, cm, } \\
\mathrm{A} & =\text { cross-sectional area, } \mathrm{cm}^{2}, \\
\mathrm{~V} & =\text { velocity, cm/sec. }
\end{aligned}
$$


Surface Mass Balance

$$
\partial \mathrm{S} / \partial \mathrm{t}=\underset{\text { Source }}{\mathrm{b}}-\underset{\text { Decay }}{\lambda \mathrm{S}}+\underset{\text { Mass Transfer }}{\mathrm{k}\left(\mathrm{C}-\mathrm{C}_{\mathrm{s}}\right)},
$$

where $S=$ surface concentration $\mu \mathrm{g} / \mathrm{cm}^{2}$,

$\mathrm{b}=$ surface source rate, $\mu \mathrm{g} / \mathrm{cm}^{2}-\mathrm{sec}$.

Equilibrium Adsorption Coupling

$$
\ln C_{S}=(\alpha+\beta / T)+(\gamma+\delta / T) \ln S,
$$

where $\mathrm{T}=$ absolute surface temperature, ${ }^{\circ} \mathrm{K}$,

$\alpha, \beta, \gamma$, and $\delta$ are constants determined experimentally.

The code has three options for treating deposition: (1) no sorption (e.g., a nonadsorbing noble gas); (2) no desorption (the surface is a perfect sink or, more precisely, the $\mathrm{C}_{\mathbf{s}}$ is zero for all surface concentrations); and (3) desorption (an adsorption isotherm is employed such that, at a given surface temperature and coolant concentration, an equilibrium surface concentration exists beyond which no further accumulation occurs, i.e.,

$\left.\mathrm{C}_{\mathbf{s}}=\mathrm{C}\right)$. The material property data that serve as input to the present plateout codes are gaseous diffusivities and sorption isotherms. Gaseous diffusitivities along with fluid properties are employed in empirical correlations to calculate convective mass transfer coefficients. The reference material property data used for the reactor design are reported in Ref. 3 .

\section{DESIGN METHODS VERIFICATION}

\subsection{Peach Bottom Experience}

3.1.1. Observations. Considerable work was done to characterize the behavior of fission products in the primary circuit of the Peach Bottom HTGR. Oak Ridge National Laboratory (ORNL) conducted a surveillance program throughout the course of Core 2 operation (Ref. 4), and an extensive end-oflife (EOL) program (Ref. 5) was performed after the reactor was shut down for decommissioning because of its uneconomically small size.

The PB primary circuit after seven years of plant operation was exceptionally clean. A fuel element purge system virtually eliminated the release of fission gases into the primary coolant; the total circulating activity never exceeded one $\mathrm{C} i$ throughout Core 2 operation (Ref. 6). The plateout distributions of gamma-emitting nuclides in the primary circuit at EOL were determined by extensive in situ gamma scanning. The dominant gamma emitters were $\mathrm{Cs}-137$ and $\mathrm{Cs}-134$; their relative distributions were similar. These cesium results were presented previously (Ref. 7).

Following the gamma scanning, a large number of samples were destructively removed from the coolant ducts and steam generator tube bundle and examined at GA. A number of relevant observations were made. First, all the specimens were coated with a thin carbonaceous film which resulted from 
the cracking of lubricating oil periodically leaked into the reactor. Gamma scanning of the specimens confirmed that only Cs-137 and Cs-134 were present above background, and the specific activities were reasonably consistent with the in situ scans. Radiochemical examination revealed $\mathrm{Sr}-90$ to be the only other fission product present in measurable concentrations, but its specific activity was about three orders of magnitude less than that of cesium. Several specimens were also analyzed for $\mathrm{Sr}-90$ content by ORNL and by the Commissariat à l'Energie Atomique (CEA). Neutron activation analysis falled to detect any I-129. Significantly, $\geq 80 \%$ of the cesium and strontium was associated with carbon film.

3.1.2. Predictions. The experimental and predicted plateout distributions for cesium and strontium are compared in Figs. la and $1 \mathrm{~b}$, the format of which is the PAD code representation of the PB primary circuit. The in situ cesium data are shown, including the collapsed steam generator data (axially and radially averaged), and all the $\mathrm{Sr}-90$ data; the scatter in $\mathrm{Sr}-90$ data is immediately evident. The specific activity is plotted as a function of fractional cumulative surface area. (Note that the abscissa is drawn to scale within a given section but the scale differs from one section to another.) Two PAD calculations for cesium are shown: (1) mass transfer control (i.e., the surfaces are perfect sinks for cesium), and (2) sorptivity control; only a perfect sink calculation is shown for strontium. In all cases, the time-average core release rate of cesium was adjusted so that the predicted specific activity at the evaporator inlet (shell side) was approximately equal to the measured value. Since the decay of $\mathrm{Xe}-137$ produced negligible amounts of Cs-137 compared to the directly released component, the relative distributions shown in Fig. la apply equally well to Cs-134, which has no gaseous precursor.

Inspection of Fig. 1 indicates that the mass transfer control, or perfect sink, case (solid lines) resulted in good agreement everywhere except for cesium in the hot duct leading from the reactor vessel to the steam generator. Here the specific cesium activity is overpredicted by an order of magnitude. Since the flow geometry is simple (a circular duct), prediction of the mass transfer coefficient should be reasonably accurate. Thus, the logical conclusion is that the cesium deposition in the hot duct is not limited by mass transfer effects but rather by the high surface temperature. Strontium deposition in the hot duct appears to be perfect sink, but the scatter in the data weakens the conclusion.

The major difficulty is choice of appropriate sorption isotherms to describe the cesium sorptive capacity of the surface. The hot duct cladding was constructed of SS304, for which sorption data are available (Ref. 8). Another complication was that the carbon film could be a significant sink for cesium. Given these uncertainties, the surface sorptivity was investigated parametrically. In summary, the experimentally observed cesium and strontium plateout distributions in PB can be predicted almost exactly with the PAD code, providing appropriate sorption isotherms are employed. However, the observed sorption behavior is consistent with either assuming that the primary cesium sink is a relatively oxide-free S\$304 surface or assuming that the carbon deposit has a cesium sorptivity intermediate to that of 


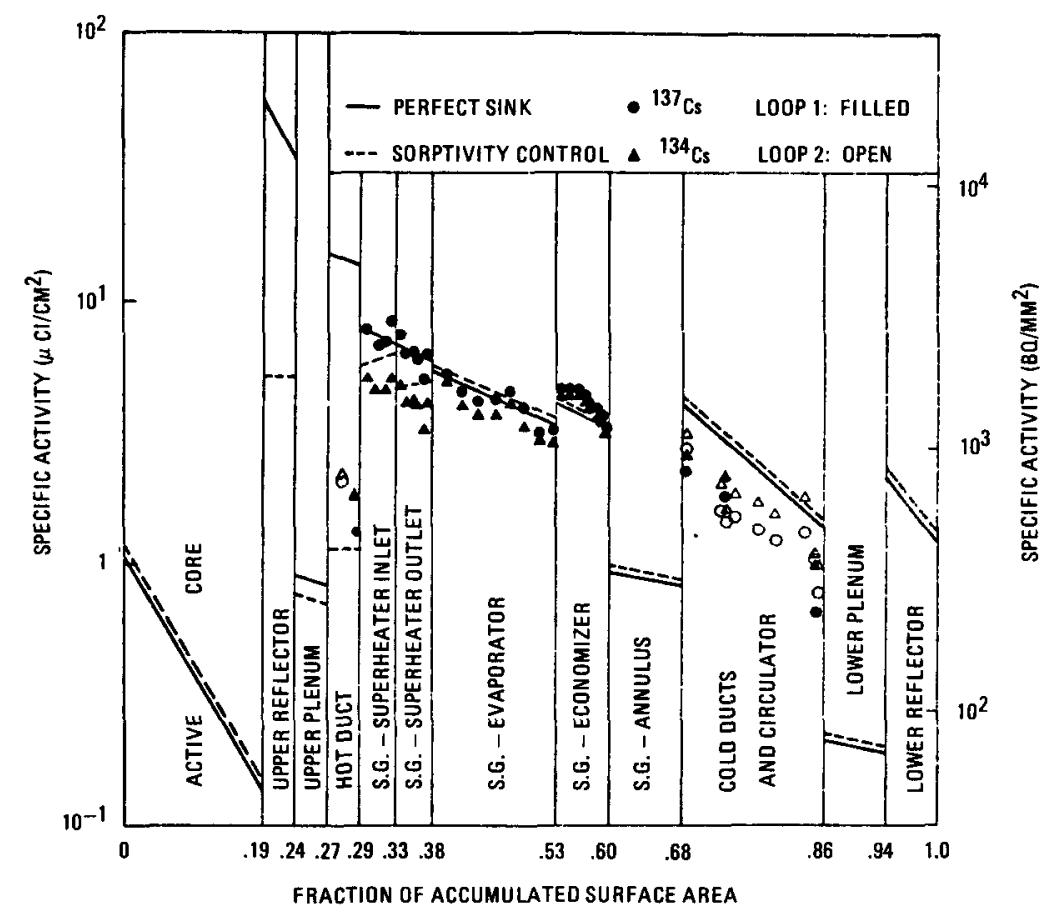

Fig. 1a. Plateout distribution of $\mathrm{Cs}-137$ and $\mathrm{Cs}-134$ in Peach Bottom HTGR

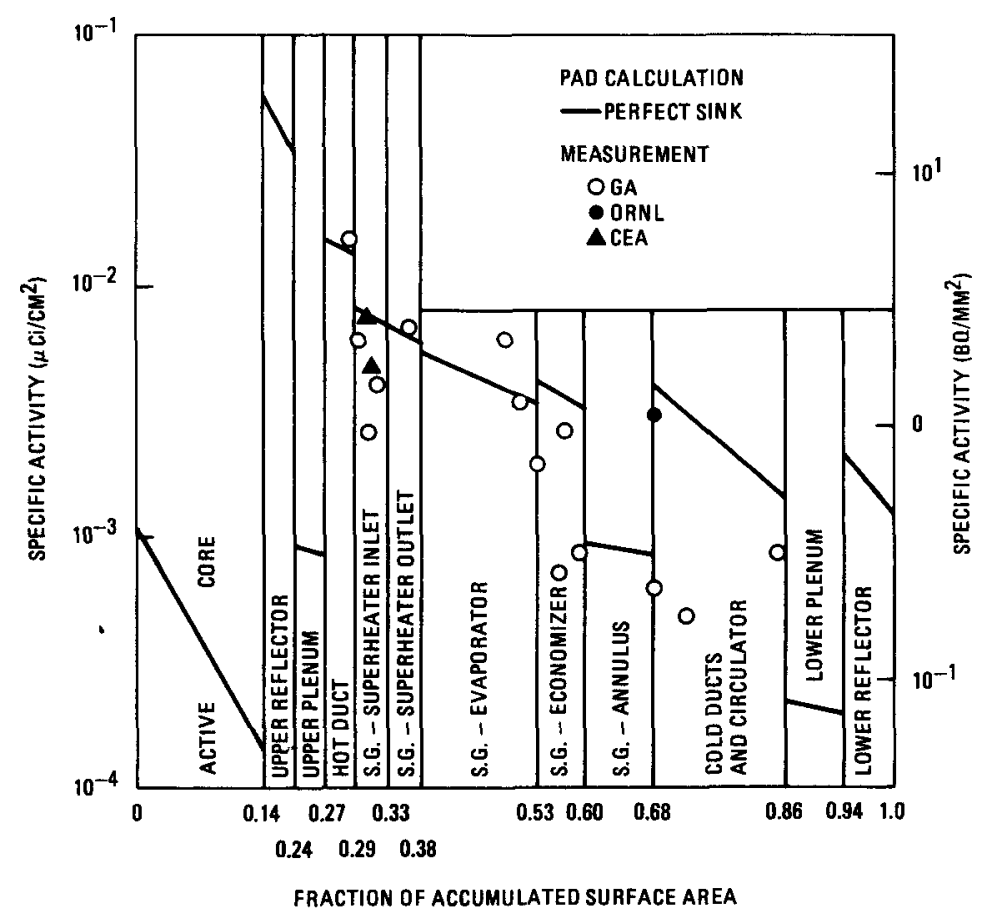

Fig. 1b. Plateout distribution of $\mathrm{Sr}-90$ in Peach Bottom Reactor 
graphite and matrix. Since most of the radioactivity was associated with carbon film, the latter appears more likely. Cesium and strontium deposition throughout the circuit was apparently mass transfer controlled with the exception of cesium in the hot duct. The profiles suggest that both cesium and strontium were transported primarily in atomic form despite the presence of carbonaceous dust. Details are given in Ref. 7 .

\subsection{FSV Experience}

Since the FSV HTGR only began commercial operation in 1979, the fission product data base for FSV is more limited than for PB. Primary coolant activity levels have been monitored throughout the operation of the plant. The release rates of noble gases from the core are measured regularly, and periodic measurements of the circulating iodine levels are made with the iodine monitor ( $\operatorname{Ref}$. 9). This device relies upon the measurement of the xenon daughters of the collected iodines and, as such, provides data for I-133 and I-135; radiologically important I-131 must be estimated by extrapolation. Some information on the plateout levels was obtained by examination of two circulators which have been removed from the prestressed concrete reactor vessel (PCRV) - one for a safety inspection (a technical specification requirement) and the other to repair a failed shutdown seal. More definitive information on the plateout levels will be obtained when the first plateout probe (Ref. 9) is removed.

3.2.1. Observations. Primary circuit activities during the first cycle were very low. Typical coolant inventories, measured at $\sim 70 \%$ power, are compared with the final safety analysis report (FSAR) design limits below; as expected, the activities are well below the design limits:

\begin{tabular}{|c|c|c|}
\hline Nuclide & $\begin{array}{c}\text { Circulating } \\
\text { Measured } \\
\end{array}$ & $\begin{array}{c}\text { Activity (Ci) } \\
\text { Design } \\
\end{array}$ \\
\hline $\begin{array}{l}I-135 \\
I-133\end{array}$ & $\begin{array}{l}0.8 \\
1.2\end{array}$ & $\begin{array}{l}53.8 \\
34.4\end{array}$ \\
\hline Total $\mathrm{Kr}$ and $\mathrm{Xe}$ & 300 & 32,300 \\
\hline
\end{tabular}

The plateout activities on the " $C$ " circulator were estimated by gamma scanning a region of the impeller prior to disassembly of the machine; results are summarized in Table 1 . Since the geometry was not ideal, there is some uncertainty in the calibration; however, subsequent analysis of a decontamination solution for $\mathrm{Cs}-137$ gave reasonably consistent results. Attempts were also made to analyze the decontamination solution for strontium by radiochemical analysis and for $I-129$ by $(n, \gamma)$ analysis; however, interference by unidentified elements in the proprietary decontamination solution was so extensive that reliable results were not obtained.

Small amounts of metallic, neutron activation products, such as $\mathrm{Cr}-51$ and Co-60, were also detected on the FSV circulator. These activation products may have been produced from small amounts of construction debris that became entrained in the helium and then activated when passing through the core. Similar low levels of these activation products were also 
TABLE 1

PLATEOUT ACTIVITY ON FSV CIRCULATOR

\begin{tabular}{l|c|c}
\hline \multirow{2}{*}{ Nuc1ide } & \multicolumn{2}{|c|}{ Specific Activity $\left(\mu \mathrm{Ci} / \mathrm{cm}^{2}(\mathrm{a})\right.$} \\
\cline { 2 - 3 } & Measured & Predicted \\
\hline $\mathrm{I}-131$ & 1.4 & 20 \\
$\mathrm{Cs}-137$ & $0.030,0.024(\mathrm{~b})$ & 0.032 \\
$\mathrm{Cs}-134$ & 0.005 & 0.001 \\
$\mathrm{Ba} / \mathrm{La}-140$ & 0.024 & 0.33 \\
$\mathrm{Zn}-65$ & 0.039 & -- \\
$\mathrm{Co}-60$ & 0.018 & - \\
$\mathrm{Cr}-51$ & 0.017 & -- \\
$\mathrm{Mn}-54$ & 0.007 & -- \\
$\mathrm{Fe}-59$ & 0.007 & -- \\
\hline
\end{tabular}

(a) $\gamma$ scan results decayed back to time of remova 1 .

(a) $Y$ analysis of leach solution. 
observed in PB. Their specific activities did not increase appreciably with operating time, and they were insignificant compared with the fission product activity. Hence, no detailed analysis of these data has been at tempted.

3.2.2. Predictions. The FSV Cycle 1 operating history has been modeled with the reference large HTGR core design codes, and the predictions from the physics to the fission products have generally been confirmed. In the fission product transport area, the emphasis has been on predicting the coolant activity levels, because those measurements are the most extensive and reliable. The measured and predicted R/Bs (release rate into coolant divided by birth rate in the fue1) for the reference nuclides $\mathrm{Kr}-85 \mathrm{~m}$ and Xe-138 are compared in Fig. 2. The comparison for other isotopes is similar. Considering just the data taken at a reactor power of $70 \%$, the measured $R / B s$ varied as the half-life to the 0.4 power rather than the expected 0.5 power. Since the subject of fuel performance is peripheral to this conference, this matter will not be discussed further here.

The circulating iodine levels were also predicted. Here the comparison is more complex because the steady-state circulating activity is established by the relative rates of core release, plateout, and helium purification. At GA it was decided to characterize the plateout rate by a so-called "plateout per pass ( $\mathrm{P} / \mathrm{P})$, " which is defined as the fractional depletion of the coolant inventory due to plateout during a single transit of the helium through the reactor circuit. In order to calculate the plateout per pass from the measured I-133 and I-135 inventories, the I-133 and I-135 release rates from the core must be assumed. It has been standard practice to assume that iodine and xenon isotopes of the same half-life have the same release characteristics. Making this assumption and using the measured 0.4 power $X e$ half-1ife dependence, the apparent $P / P$ rates for $I-133$ and $I-135$ were calculated and are plotted versus half-life in Fig. 3. Also shown is the predicted relationship between $P / P$ and $T_{1 / 2}$ as calculated with the PADLOC code using sorption isotherms measured by CEA (Ref. 10). Since the CEA isotherms are linear, the predicted $P / P$ is independent of the core release rate and dependent only upon the half-life. Although the predicted slope appears consistent with the measurements, the absolute value is too low. When the absolute sorptivity is increased by a factor of five, the agreement is much improved. (There is considerable evidence from the CPL 2 test program that these isotherms have the correct temperature dependence but underpredict the absolute sorptivity.)

The levels of fission products on the circulator were also predicted and compared with measurements in Table 1. Again, the problem is that these predictions depend upon both the release rate from the core and the plateout distribution. The results are mixed. The Cs-137 activity was well predicted, but the Cs-134 was underpredicted by a factor of five; the latter discrepancy could result from errors in predicting the amount of Cs-134 produced by activation of $\mathrm{Cs}-133$, the release rate, the plateout distribution, or a combination othereof. The specific Ba/La-140 activity was overpredicted by an order of magnitude. It is speculated that the release of the 
6

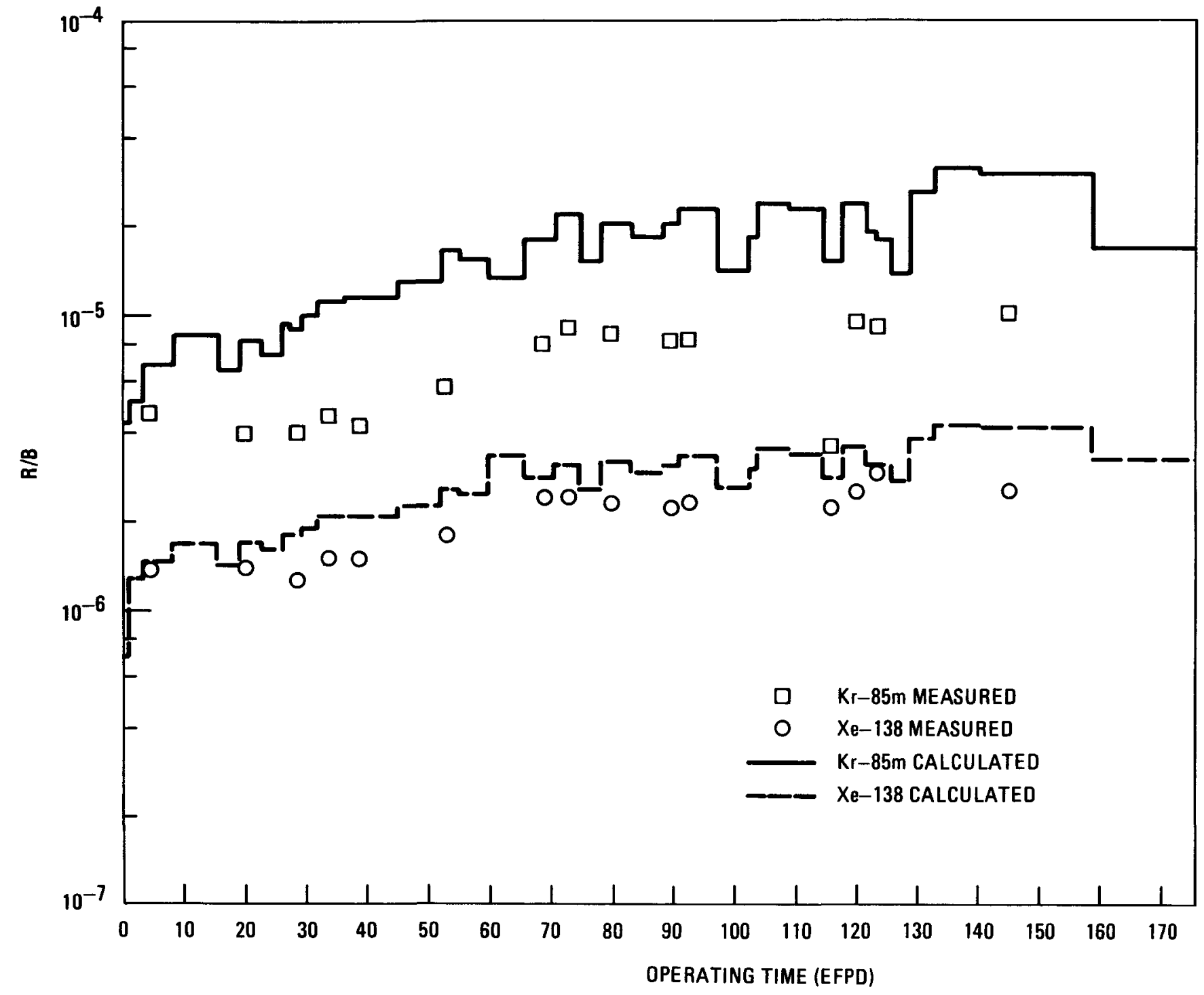

Fig. 2. Comparison of measured and calculated fission gas release for FSV cycle 1 


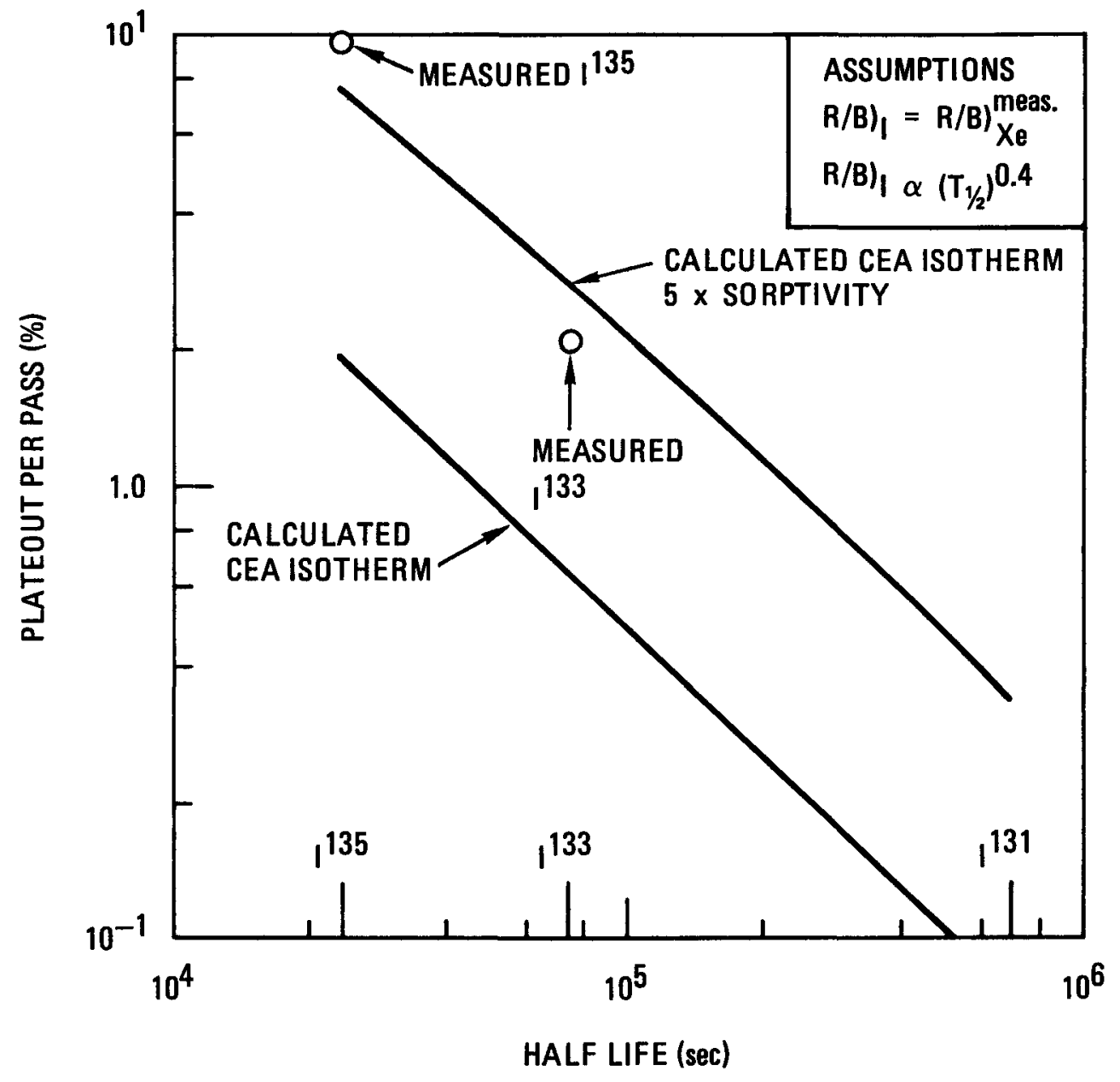

Fig. 3. Iodine plateout per pass in FSV, cycle 1 
14-sec Xe-140 precursor was overpredicted because the reference design methods do not account for the attenuation of short-lived gases by the graphite web of the fuel element. The amount of I-13I was overpredicted by more than an order of magnitude. Some of the discrepancy likely resulted from an overestimation of the core release rate. Nevertheless, the measured I-131 plateout activity on the circulator and the I-133 and I-135 circulating activities do seem inconsistent. Data from the plateout probe should resolve this apparent discrepancy.

\section{DISCUSSION}

The levels of fission products in the primary circuits of both $P B$ and FSV were quite low, well below the design limits. However, the "mix," or composition, of fission products in the two HTGRs is quite different: the PB circuit at EOL contained only the long-lived volatile fission metals and negligible fission gases; the FSV circuit during the first cycle contained primarily fission gases and their solid daughter products. Differences in core design and in operating history are responsible. The purge system in $\mathrm{PB}$ virtually eliminated the release of fission gases; even though the quality of fuel in FSV is far better than that used in PB, the nonpurged core design releases more fission gases into the primary circuit. PB Core 2 operated for 897 effective full-power days (EFPD); but FSV Cycle 1 was 175 EFPD, and the power level never exceeded $70 \%$. As the burnup of the FSV core increases and the power level rises, the mix of fission products may well change.

Overall, the PB and FSV operational data verify the design methods used to predict circuit activities for the large HTGR. The PAD and PADLOC codes appear to be adequate empirical tools for prediction of plateout distributions provided that appropriate material data, the most important of which are the sorption isotherms, are available. While these results are encouraging, additional design verification is needed, and the ongoing FSV surveillance program should provide much of the needed data.

\section{ACKNOWLEDGMENT}

This work was supported by the U.S. Department of Energy under Contract DE-AT03-76ET35300.

\section{REFERENCES}

1. Hudritsch, W. W., and P. D. Smith, "PADLOC, A One-Dimensional Computer Program for Calculating Coolant and Plateout Fission Product Concentrations," DOE Report GA-A14401, General Atomic Company, November 1977.

2. Vanslager, F. E., and L. D. Mears, "PAD: A Computer Code for Calculating the Plateout Activity Distribution in a Reactor Circuit," Gulf General Atomic Report GA-10460, January 1971. 
3. "HTGR Accident Initiation and Progression Analysis Status Report, Vol. 5, AIPA Fission Product Source Terms," DOE Report GA-A13617, General Atomic Company, February 1976.

4. Dyer, F. F., et al., "Distribution of Radionuclides in the Peach Bottom HTGR Primary Circuit During Core 2 Operation," ERDA Report ORNL-5188, Oak Ridge National Laboratory, March 1977.

5. Steward, K. P., "Final Summary Report on the Peach Bottom End-of-Life Program," DOE Report GA-A14404, General Atomic Company, Ju1y 1978.

6. Hanson, D. L., and N. L. Baldwin, "Fission Gas Release from Core 2 of the Peach Bottom HTGR," ANS Transactions TANSO 28, 688 (1978).

7. Hanson, D. L., N. L. Baldwin, and W. E. Selph, "Gamma Scanning the Primary Circuit of the Peach Bottom HTGR," USERDA Report GA-Al4161, General Atomic Company, October 31, 1976. Also ANS Transactions TANSO 24, 403 (1976).

8. Milstead, C. E., and L. R. Zumwalt, "Cesium Deposition on Stainless Stee1," Nuc1. Appl. 3, 495 (1967).

9. Hanson, D. L., N. L. Baldwin, and D. Albertstein, "Fort St. Vrain P1ateout Probes," General Atomic Report GA-A14402, October, 1977.

10. Blanchard R., CEA, unpublished data. 